\title{
LOKAKARYA FUN LEARNING BERSAMA SMA FAVORIT DI JAKARTA: TEORI GRIT DAN GROWTH MINDSET LEBIH SULIT DARI FLOW
}

\author{
Ihan Martoyo ${ }^{1,2}$, Mario Gracio A. Rhizma ${ }^{1}$, Marincan Pardede ${ }^{1}$, Junita ${ }^{1}$, Julinda Pangaribuan ${ }^{1}$, \\ Henri P. Uranus ${ }^{1}$, Herman Kanalebe ${ }^{1}$, Rocky T. Putra ${ }^{1}$, Rianto Mangunsong ${ }^{1}$, Heri Yulian ${ }^{1}$, \\ ${ }^{1}$ Teknik Elektro Universitas Pelita Harapan, Tangerang 15811, Indonesia \\ ${ }^{2}$ Sekolah Tinggi Teologi Reformed Indonesia, Kemang, Jakarta 12760, Indonesia \\ e-Mail: ihan.martoyo@uph.edu
}

\begin{abstract}
Abstrak
Program Studi Teknik Elektro Universitas Pelita Harapan secara berkala melakukan lokakarya bersama berbagai sekolah untuk membagikan konsep fun learning, yang bertumpu pada 3 teori psikologi: teori flow, teori grit dan teori growth mindset. Walaupun proses pembelajaran modern sudah melibatkan banyak teknologi digital, kualitas pembelajaran itu sendiri diyakini lebih ditentukan oleh teori psikologi yang diterapkan daripada teknologi yang dipakai. Lokakarya kali ini dilakukan bersama guru-guru dari sebuah SMA favorit di Jakarta. Konsep fun learning yang dipresentasikan dilanjutkan dengan diskusi tentang kesulitan menerapkan konsepkonsep tersebut dalam aktivitas belajar yang sesungguhnya. Selain itu, dalam lokakarya juga dilakukan demonstrasi konsep-konsep fisika optik dengan laser dan kotak cahaya sederhana. Demonstrasi dengan peralatan sederhana ini diharapkan dapat dimanfaatkan untuk pembelajaran yang menyenangkan. Diskusi dengan para guru menunjukkan bahwa konsep grit dan growth mindset lebih sulit dipraktikkan dibandingkan konsep flow. Hasil pre-test dan post-test juga menunjukkan bahwa konsep flow lebih mudah ditangkap daripada teori grit dan growth mindset.
\end{abstract}

Kata Kunci: Fun Learning, Flow, Grit, Growth Mindset

\section{PENDAHULUAN}

Walaupun pembelajaran modern sudah sering melibatkan berbagai instrumen digital seperti materi multimedia atau sistem e-learning, namun kualitas pembelajaran sebenarnya tergantung dari interaksi dalam aktivitas pembelajaran itu sendiri (Martoyo, Purbojo \& Susilo, 2007). Memindahkan pola belajar dalam kelas tradisional begitu saja ke dalam format digital tidak serta-merta membuat pembelajaran menjadi lebih menyenangkan atau lebih baik. Diperlukan aplikasi teori psikologi pendidikan yang sudah teruji untuk membentuk fun learning.
Beberapa teori psikologi pendidikan yang dapat dimanfaatkan untuk membentuk konsep fun learning adalah: teori flow, teori grit dan teori growth mindset (Martoyo et al., 2018). Teori flow menjelaskan suatu kondisi di mana seseorang larut dalam aktivitas yang dilakukan ketika tantangan dari tugas yang dikerjakan sulit, namun sesuai dengan tingkat kemampuan (skill) dari orang tersebut (Csikszentmihalyi, 1991; Martoyo et al., 2018). Pengalaman flow (larut dalam aktivitas) ini dapat dialami dalam berbagai profesi yang menuntut suatu skill yang tinggi: Pemusik, penari, olahragawan, ilmuwan, dan sebagainya. Jika seseorang mengalami flow dalam proses belajar, maka ia akan merasakan proses belajar itu sebagai

$$
\text { Pendidikan } \quad 808
$$


hal yang menyenangkan. Flow bahkan merupakan bagian dari kebahagiaan itu sendiri (Csikszentmihalyi, 2014).

Teori grit menjelaskan suatu karakter yang terdiri dari: (1) Ketekunan atau sikap pantang menyerah (perseverance), dan (2) kecintaan pada bidang yang digeluti (passion), untuk jangka waktu yang panjang (Duckworth, Peterson, Matthews, \& Kelly, 2007; Martoyo et al., 2018). Seseorang yang menunjukkan grit akan bertahan dalam kesulitan proses belajar melalui waktu yang panjang, dengan terus didorong oleh rasa kecintaan pada bidang yang digeluti. Penelitian menunjukkan bahwa grit dapat memprediksi prestasi belajar mahasiswa (Pate et al., 2017), dan berhubungan secara negatif dengan stress (Lee, 2017). Proses belajar yang sulit, jika disertai dengan grit, akan dapat menjadi pengalaman yang menyenangkan.

Teori growth mindset menjelaskan suatu kondisi mental yang mengasumsikan bahwa seseorang dapat bertumbuh (grow) dalam kapasitas kemampuannya, dan skill seseorang bukanlah sifat/bakat yang fixed dari lahir (Dweck, 2009; Martoyo et al., 2018). Banyak siswa melihat diri sebagai mempunyai bakat atau kemampuan intelektual tertentu yang tak dapat berubah (fixed mindset). Walaupun cukup pandai, seseorang dengan fixed mindset akan menghindari tantangan yang lebih besar karena kegagalan akan memperlihatkan bahwa dia tidak pandai. Sebaliknya, seseorang dengan growth mindset dapat lebih leluasa menerima tantangan belajar yang lebih besar, karena meyakini kemampuan seseorang dapat bertumbuh (growth mindset), dan bukan ditentukan oleh bakat atau IQ yang fixed dari lahir.

Kegiatan Pengabdian kepada Masyarakat (PkM) yang dilakukan program studi Teknik Elektro UPH adalah membagikan ketiga teori flow, grit dan growth mindset ini melalui lokakarya dengan sebuah SMA favorit di Jakarta. Presentasi ketiga teori psikologi untuk membentuk fun learning dilanjutkan dengan diskusi tentang kesulitan penerapan dari konsep-konsep tersebut.

Selain itu juga dilakukan demonstrasi berbagai fenomena fisika optik dengan peralatan sederhana dengan laser dan kotak cahaya. Penggunaan berbagai alat sederhana untuk demonstrasi efek optik ini diharapkan dapat dimanfaatkan untuk membentuk fun learning dalam pelajaran fisika.

Dalam kegiatan PkM ini juga disumbangkan beberapa eksemplar buku mengenai teori yang dipresentasikan (grit dan growth mindset), serta satu buku mengenai penerapan elearning. Interaksi dan diskusi menghasilkan berbagai pemahaman yang lebih mendalam terhadap konsep yang dibagikan dan kesulitan penerapan konsep tersebut. Untuk menangkap pemahaman dan opini mengenai konsep yang dibagikan dilakukan dengan melakukan pre-test dan post-test.

\section{METODE}

Kegiatan PkM dimulai dengan persiapan materi presentasi, persiapan peralatan untuk demonstrasi fisika optik, seleksi dan penyediaan buku-buku yang akan disumbangkan serta penjadwalan lokakarya. Teori psikologi mengenai flow, grit dan growth mindset diharapkan dapat memberikan gambaran untuk membentuk desain pembelajaran fun learning. Demonstrasi fenomena fisika optik dengan peralatan laser dan kotak cahaya sederhana juga diharapkan memicu berbagai ide untuk pembelajaran yang lebih menyenangkan, khususnya dalam bidang fisika.

Pre-test dan post-test yang digunakan untuk mengukur pemahaman setelah lokakarya tampak pada Tabel 1. Pertanyaan nomor 1, 6 dan 7 dibalik arahnya untuk menangkap perubahan pemahaman dengan lebih tajam.

Tabel 1. Kuesioner pre-test dan post-test

\begin{tabular}{|l|l|l|}
\hline No & Pre-test & Post-test \\
\hline 1 & $\begin{array}{l}\text { Pelajaran yang mudah } \\
\text { lebih dapat menjadi fun } \\
\text { learning dibanding } \\
\text { pelajaran yang sulit }\end{array}$ & $\begin{array}{l}\text { Pelajaran yang sulit } \\
\text { punya potensi dibuat } \\
\text { fun learning karena } \\
\text { dapat menimbulkan } \\
\text { flow }\end{array}$ \\
\hline 2 & $\begin{array}{l}\text { Pelajaran fisika atau } \\
\text { matematika sulit dibuat } \\
\text { fun }\end{array}$ & $\begin{array}{l}\text { Pelajaran fisika atau } \\
\text { matematika sulit dibuat } \\
\text { fun }\end{array}$ \\
\hline 3 & $\begin{array}{l}\text { Pembelajaran dari } \\
\text { teman sama pentingnya } \\
\text { dengan dari guru }\end{array}$ & $\begin{array}{l}\text { Pembelajaran } \\
\text { dengan/dari teman } \\
\text { dapat lebih efektif } \\
\text { dibandingkan dari guru }\end{array}$ \\
\hline 4 & Anak yang pintar lebih & Anak yang pintar lebih \\
\hline
\end{tabular}




\begin{tabular}{|c|c|c|}
\hline & $\begin{array}{l}\text { mudah mengalami fun } \\
\text { learning }\end{array}$ & $\begin{array}{l}\text { mudah mengalami fun } \\
\text { learning }\end{array}$ \\
\hline 5 & $\begin{array}{l}\text { Kecerdasan atau IQ } \\
\text { adalah faktor yang } \\
\text { paling menentukan di } \\
\text { sekolah }\end{array}$ & $\begin{array}{l}\text { Kecerdasan atau IQ } \\
\text { adalah faktor yang } \\
\text { paling menentukan di } \\
\text { sekolah }\end{array}$ \\
\hline 6 & $\begin{array}{l}\text { IQ lebih menentukan } \\
\text { keberhasilan hidup } \\
\text { seseorang dibandingkan } \\
\text { kerja keras }\end{array}$ & $\begin{array}{l}\text { Daya tahan dan passion } \\
\text { lebih menentukan } \\
\text { keberhasilan hidup } \\
\text { daripada IQ seseorang }\end{array}$ \\
\hline 7 & $\begin{array}{l}\text { Memuji anak sebagai } \\
\text { anak pintar } \\
\text { membantu dia } \\
\text { lebih baik }\end{array}$ & $\begin{array}{l}\text { Memuji anak sebagai } \\
\text { anak pintar justru } \\
\text { sering merugikan }\end{array}$ \\
\hline 8 & $\begin{array}{l}\text { Anak yang dianggap } \\
\text { (menganggap diri) lebih } \\
\text { pintar lebih mudah } \\
\text { menerima tantangan }\end{array}$ & $\begin{array}{l}\text { Anak yang dianggap } \\
\text { (menganggap diri) } \\
\text { pintar lebih mudah } \\
\text { menerima tantangan }\end{array}$ \\
\hline
\end{tabular}

\section{HASIL DAN PEMBAHASAN}

\section{Presentasi dan Diskusi Teori Flow, Grit dan Growth Mindset}

Presentasi teori flow, grit dan growth mindset untuk membentuk fun learning diikuti dengan diskusi yang cukup intensif (Gambar 1 dan Gambar 2). Beberapa guru berkomentar bahwa konsep flow dapat cukup mudah diterapkan dengan memberikan tantangan tugas belajar yang bervariasi agar siswa dengan kemampuan yang berbeda tetap mempunyai potensi untuk masuk ke dalam pengalaman flow (larut dalam tugas) yang sesuai dengan tingkat skill mereka, sehingga memberikan pengalaman belajar yang menyenangkan.

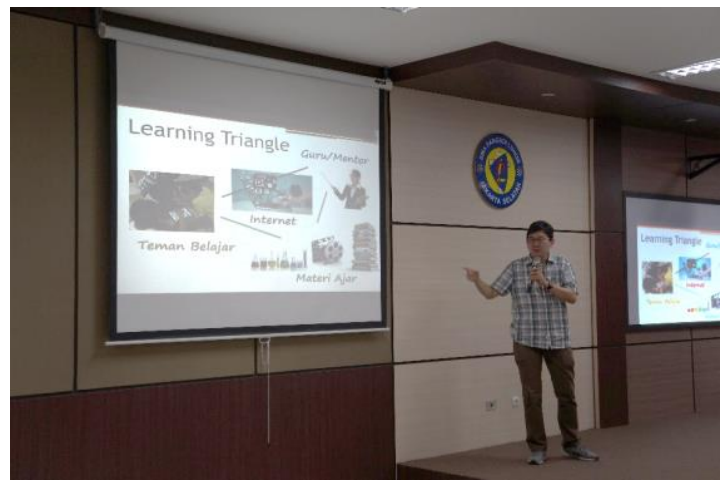

Gambar 1. Presentasi teori flow, grit dan growth mindset dalam proses belajar

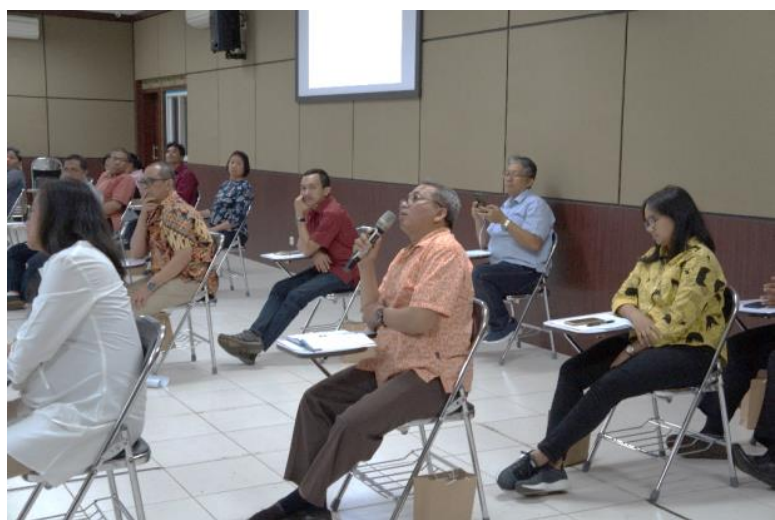

Gambar 2. Diskusi konsep flow, grit dan growth mindset

Menurut para guru, yang lebih sulit untuk diterapkan adalah konsep grit dan growth mindset. "Bagaimana membangkitkan kecintaan pada bidang ilmu yang dipelajari?" tanya beberapa guru. Memang membangkitkan semangat daya tahan (perseverance) dan kecintaan pada bidang yang digeluti (passion) seperti yang dinyatakan dalam teori grit membutuhkan role model dari guru-guru dan lingkungan.

Hal yang dapat menolong untuk memodelkan daya tahan bagi siswa adalah jika guru terbuka menceritakan kisah kegagalan mereka dan bagaimana mereka keluar dari kegagalan tersebut. Ini bukan hal lumrah untuk dilakukan, karena kisah kegagalan sering bukanlah kisah yang membanggakan. Namun jika siswa dibekali dengan narasi bahwa kegagalan itu hal yang biasa terjadi dalam proses pembelajaran, maka mereka lebih mudah menyusun strategi belajar dan bertahan dalam proses pembelajaran tersebut.

Kecintaan pada bidang yang digeluti juga dapat dimodelkan oleh guru yang mengajar. Guru bukan saja dapat menunjukkan substansi keilmuan dan kompetensi dalam bidangnya, namun juga dapat menunjukkan betapa mempesonanya bidang yang digeluti dengan berbagai misteri dan hal menarik yang dapat muncul dalam bidang ilmu tersebut. Namun hal semacam ini biasanya baru dapat dilakukan secara otentik jika guru yang bersangkutan memang juga mencintai bidang yang digelutinya.

Harus diakui bahwa soal "cinta" dapat menjadi sulit, karena rasa cinta pada bidang ilmu itu

$$
\text { Pendidikan }
$$


tak dapat dipaksakan. Yang dapat dilakukan adalah membentuk suatu lingkungan belajar yang berpotensi menularkan rasa cinta tersebut.

\section{Demonstrasi Fisika Optik}

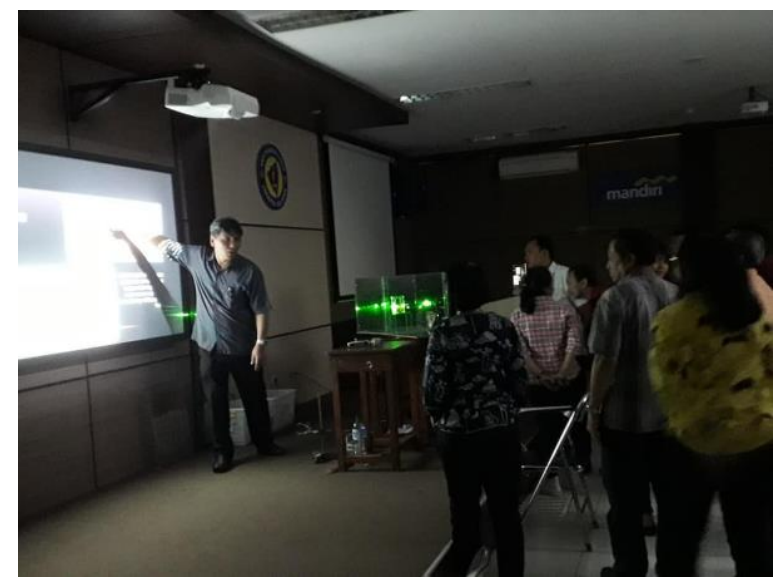

Gambar 3. Demonstrasi laser dan kotak cahaya

Dalam lokakarya ini juga diadakan demonstrasi fenomena fisika optik dengan peralatan sederhana. Demonstrasi ini meliputi: spektrometer sederhana dengan memanfaatkan pecahan CD (compact disk), (2) demonstrasi fenomena pelangi dengan prisma menggunakan air, (3) demonstrasi refraksi dan pemantulan laser ke dalam air, serta (4) demonstrasi fenomena sunset dengan larutan susu yang menyebabkan absorpsi terhadap panjang gelombang cahaya tertentu.

Penggunaan material sederhana seperti kotak cahaya yang dibuat dari akrilik untuk menangkap berkas cahaya dalam asap, sengaja dilakukan untuk menginspirasi penggunaan material sederhana dan murah untuk demonstrasi berbagai prinsip fisika. Jika metode ini dapat direplikasi, maka keingintahuan siswa dapat dipicu lewat demonstrasi semacam ini, dan kecintaan pada bidang ilmu tertentu dapat dikembangkan.

\section{Hasil Pre-Test dan Post-Test}

Tabel 2 menunjukkan nilai rata-rata dari pre-test dan post-test yang didapat dari 13 orang guru yang hadir dan mengisi kuesioner. Pertanyaan no. 1 (Tabel 1) menunjukkan perubahan opini yang cukup drastis, dari hasil pre-test yang cenderung menganggap bahwa pelajaran yang lebih mudah yang dapat dibuat fun, lantas berubah menjadi sangat setuju (3,75 dari 5) bahwa pelajaran yang sulit-lah yang berpotensi dibuat fun learning karena dapat menghasilkan pengalaman flow. Hasil ini juga sejalan dengan opini terhadap pertanyaan no. 2 yang cenderung tidak setuju bahwa pelajaran fisika atau matematika sukar dibuat fun (2,31 dan 2,08 dari 5).

Hasil lain yang cukup menarik adalah dari pertanyaan no. 6. Dari hasil pre-test yang cenderung tidak setuju bahwa IQ menentukan keberhasilan hidup (1,92 dari 5), ternyata tidak berubah menjadi positif pada pertanyaan post-test yang dibalik. Nilai post-test menunjukkan bahwa guru cenderung ragu bahwa daya tahan dan passion lebih menentukan keberhasilan hidup (hanya 3,17 dari 5).

Ini menunjukkan bahwa klaim dari teori grit yaitu bahwa karakter seperti daya tahan dan kecintaan pada bidang ilmu adalah lebih menentukan dari kecerdasan kognitif semata, cenderung sulit dipahami. Ada kemungkinan juga bahwa di sekolah yang terhitung sekolah favorit, kecerdasan kognitif yang sering muncul sebagai kemampuan matematis yang dipengaruhi IQ memang mendapatkan apresiasi yang lebih tinggi.

Tabel 2. Nilai rata-rata pre-test dan post-test

\begin{tabular}{|c|c|c|}
\hline No & Pre-test & Post-test \\
\hline 1 & $\mathbf{3 , 3 9}$ & $\mathbf{3 , 7 5}$ \\
\hline 2 & 2,31 & 2,08 \\
\hline 3 & 3,85 & 2,92 \\
\hline 4 & 3,15 & 3,17 \\
\hline 5 & 2,46 & 2,67 \\
\hline 6 & $\mathbf{1 , 9 2}$ & $\mathbf{3 , 1 7}$ \\
\hline 7 & $\mathbf{4 , 0 7}$ & $\mathbf{2 , 5 8}$ \\
\hline 8 & 3,39 & 3,42 \\
\hline
\end{tabular}

Konsep growth mindset juga termasuk hal yang tampaknya sulit dipahami. Teori growth mindset menjelaskan bahwa memuji siswa sebagai anak yang pintar justru merugikan karena dapat menimbulkan kesan bahwa kepintaran itu suatu kemampuan yang fixed dan tidak berkembang lagi. Pujian yang demikian akan membuat anak yang dilabel pintar enggan untuk menerima tantangan yang lebih berat, karena prospek kegagalan akan mengancam predikat "pintar" yang dikenakan pada

$$
\text { Pendidikan }
$$


dirinya. Menurut teori, adalah lebih baik jika yang dipuji adalah usaha (effort) yang ditunjukkan siswa daripada kepintarannya. Ketika usahanya yang dipuji, siswa akan lebih fokus kepada proses belajar sehingga growth mindset dapat dipupuk. Nilai ratarata kuesioner pada pertanyaan no. 7 dan no. 8 menunjukkan bahwa konsep growth mindset yang demikian sulit dimengerti.

\section{KESIMPULAN}

Secara teori, fun learning dapat dibentuk dengan menerapkan teori flow, grit dan growth mindset. Namun dari hasil lokakarya, tampak bahwa teori flow lebih mudah dipahami dan diterapkan daripada teori grit dan growth mindset.

Selama diskusi dalam lokakarya, guru-guru yang hadir menceritakan kisah seorang siswa yang belajar dengan fokus, bahkan tekun berlatih soalsoal sulit karena keinginan yang kuat untuk masuk PTN. Menurut gurunya, siswa ini bahkan tidak memedulikan teman-temannya yang sibuk bermain, dan sering ditemukan fokus dengan aktivitas belajarnya seorang diri.

Kisah semacam ini sebenarnya dapat saja memberikan gambaran tentang flow, grit dan growth mindset. Siswa tersebut larut dalam pembelajaran (flow), bahkan berlatih soal-soal sulit (daya tahan), dan termotivasi kuat untuk masuk PTN (passion), dan berkeyakinan bahwa kemampuan matematikanya akan meningkat dengan latihan-latihan sulit tersebut (growth mindset).

Namun demikian, kisah kasus tersebut dapat juga dimengerti secara klasik sebagai kisah anak pintar (fixed mindset) yang memang rajin belajar karena dia pintar (bukan karena grit). Dari hasil pre-test dan post-test, tampaknya pemahaman klasik seperti ini yang masih dirasakan banyak guru.

Walaupun sudah dibuktikan dalam berbagai penelitian, teori grit dan growth mindset tampaknya masih cukup sulit dipahami dan diterapkan dibandingkan konsep flow. Hal ini juga dikonfirmasi dalam ajang diskusi dengan para guru. Lokakarya serupa di kemudian hari dapat disertai dengan diskusi berbagai skenario konkret pembelajaran di mana teori-teori tersebut dapat diterapkan.

\section{UCAPAN TERIMAKASIH}

Kegiatan PkM ini didukung oleh LPPM UPH dengan nomor PM-015/FaST/I/2019.

\section{REFERENSI}

Csikszentmihalyi, M. (1991). Flow: The psychology of optimal experience. New York: HarperPerennial.

Csikszentmihalyi, $\quad$ M. (2014). Learning,"flow," and happiness. In Applications of flow in human development and education (pp. 153172). Springer, Dordrecht.

Duckworth, A. L., Peterson, C., Matthews, M. D., \& Kelly, D. R. (2007). Grit: perseverance and passion for long-term goals. Journal of personality and social psychology, 92(6), 1087.

Dweck, C. S. (2009). Mindsets: Developing talent through a growth mindset. Olympic Coach, 21(1), 4-7.

Martoyo, I., Purbojo, R., \& Susilo, Y. (2007). E-learning \& Constructivism: Ketika Pendidikan Bersanding dengan Teknologi. Tangerang: UPH Press.

Martoyo, I., et al. (2018). Lokakarya Fun Learning dengan Flow, Grit \& Growth Mindset. Jurnal Sinergitas PKM \& CSR, 3(1), 35-43.

Pate, A. N., Payakachat, N., Harrell, T. K., Pate, K. A., Caldwell, D. J., \& Franks, A. M. (2017). Measurement of grit and correlation to student pharmacist academic performance. American journal of pharmaceutical education, 81(6), 105.

Lee, W. W. S. (2017). Relationships among grit, academic performance, perceived academic failure, and stress in associate degree students. Journal of adolescence, 60, 148-152 
